\title{
Schineria larvae gen. nov., sp. nov., isolated from the 1st and 2nd larval stages of Wohlfahrtia magnifica (Diptera: Sarcophagidae)
}

\author{
Erika Tóth, ${ }^{1}$ Gábor Kovács, ${ }^{1}$ Peter Schumann, ${ }^{2}$ Attila L. Kovács, ${ }^{3}$ \\ Ulrike Steiner, ${ }^{2}$ András Halbritter ${ }^{1} \dagger$ and Károly Márialigeti ${ }^{1}$
}

\footnotetext{
1 Department of Microbiology, Eötvös Loránd University, $\mathrm{H}-1088$ Budapest, Múzeum krt. 4/a, Hungary

2 Deutsche Sammlung von Mikroorganismen und Zellkulturen $\mathrm{GmbH}$, Braunschweig, Germany

3 Department of General Zoology, Eötvös Loránd University, Budapest Hungary
}

\author{
Author for correspondence: Erika Tóth. Tel: +361266 1148. Fax: +3612661148. \\ e-mail: totherika@ludens.elte.hu
}

\begin{abstract}
Four bacterial strains were isolated from the fly larvae of an obligate parasitic fly, Wohlfahrtia magnifica (Diptera: Sarcophagidae). These isolates were characterized by a polyphasic approach and represent a new lineage of $\gamma$ Proteobacteria as their closest relative is Xylella fastidiosa (87.1\% 16S rDNA similarity). The four strains are identical at the $16 \mathrm{~S}$ rDNA level, the level of similarity between them, based on DNA-DNA hybridization, is high $(97.8-102.5 \%)$ and they are similar in their physiological and biochemical characteristics, although they differ in their utilization of different sole carbon sources. All produce chitinase. They are obligately aerobic: no growth is detected under anaerobic conditions, even in the presence of $\mathrm{NO}_{3}^{-}$as terminal electron acceptor. Their predominant respiratory quinone is Q-8. The G+C content of their DNA is $\mathbf{4 2} \mathbf{~ m o l} \%$. Their cell membrane contains phosphatidylglycerol, diphosphatidylglycerol, phosphatidylethanolamine, phosphatidylserine and two unknown polar lipids. Their main fatty acids are $C_{18: 1}, C_{16: 0}$ and $C_{14: 0}$. To accommodate these bacteria, a new genus, Schineria gen. nov., with the type species Schineria larvae sp. nov., is proposed.
\end{abstract}

Keywords: Schineria larvae, myiasis, fly, gamma-Proteobacteria, taxonomy

\section{INTRODUCTION}

It is generally accepted that one of the basic resources for bacterial species diversity is the world of insects. They are speculated to harbour thousands of novel bacterial symbionts (parasites, mutualistic partners or protoco-operants). This supposition seems to be corroborated by numerous publications (Cruden \& Markovetz, 1984; Ishikawa, 1989; Groombridge, 1992; Tanada \& Kaya, 1993; Cazemier et al., 1997) and recent investigations on traumatic myiasis support this opinion (Khoga, 1994; Tóth et al., 1998). Myiasis

\footnotetext{
† Present address: Research Institute for Soil Science and Agricultural Chemistry, Budapest, Hungary.

Abbreviations: DPG, diphosphatidylglycerol; PE, phosphatidylethanolamine; PG, phosphatidylglycerol; PS, phosphatidylserine; TEM, transmission electron microscopy.

The GenBank accession numbers for the 16S rDNA sequence of strains L1/68 ${ }^{\top}, L 1 / 57, L 1 / 58$ and L2/11 are AJ252143, AJ252144, AJ252145 and AJ252146, respectively.
}

is a disease of vertebrate animals caused by different fly larvae. The obligate parasitic fly (developing on/in the tissues of living animals, like sheep, goats, camels, geese, turkeys, etc.) Wohlfahrtia magnifica (Diptera: Sarcophagidae) (Schiner, 1862) is responsible for serious losses in animal husbandry in Eurasia (Martinez et al., 1987, 1991; Hall \& Wall, 1995; Farkas et al., 1997; Hall, 1997; Valentin et al., 1997). There is scant information about the aetiology of the disease. During studies in the field, detailed bacteriological investigations have been carried out on the different developmental stages of the fly (1st, 2nd, 3rd stage larvae, pupae and imago). Among the bacterial strains isolated from the fly larvae, some were found to strongly utilize chitin and represent a separate phylogenetic line of descent. The isolation, characterization and taxonomic delineation of strains $\mathrm{L} 1 / 68^{\mathrm{T}}, \mathrm{L} 1 / 57$, $\mathrm{L} 1 / 58$ and $\mathrm{L} 2 / 11$ are described in this paper. We propose a new genus, Schineria gen. nov. and the species Schineria larvae sp. nov. to accommodate these bacteria. 


\section{METHODS}

Isolation and cultivation. Strains $\mathrm{L} 1 / 68^{\mathrm{T}}, \mathrm{L1} / 57$ and $\mathrm{L} 1 / 58$ were isolated from whole larval macerate of 1 st stage larvae and L2/11 was isolated from 2nd stage larvae of Wohlfahrtia magnifica (Schiner, 1862) as follows. Larvae were collected from the vulval wound of Romney breed sheep at Mezõfalva State Farm $\left(18^{\circ} 40^{\prime} \mathrm{E}, 46^{\circ} 50^{\prime} \mathrm{N}\right)$, Hungary, in 1997. They were identified both to species level and for developmental stage by stereomicroscopic investigation. They were washed three times in sterile $0.025 \mathrm{M}$ sodium phosphate buffer solution ( $\mathrm{pH} \mathrm{6.8)}$ ) and then homogenized in 0.025 M sodium phosphate buffer under aseptic conditions. All bacterial strains were isolated, grown and later subcultured and maintained on King B agar medium (King, 1954).

Morphology. Colony morphology was tested on King B agar medium by direct and stereomicroscopic observations of single colonies. Cell morphology and motility were studied by phase-contrast microscopy of native preparations. Gram staining was performed according to Claus (1992), spore staining according to Smibert \& Krieg (1994) and capsules were visualized by negative staining according to Duguid (1951). Bacteria were prepared for ultrastructural study by transmission electron microscopy (TEM) as follows. Cells were grown on King B agar plates for $24 \mathrm{~h}$ at $28^{\circ} \mathrm{C}$, then fixed in $1 \%$ glutaraldehyde solution buffered with sodium cacodylate $(0 \cdot 1 \mathrm{M}, \mathrm{pH} \mathrm{7 \cdot 2)}$ for $2 \mathrm{~h}$ at room temperature. The fixed samples were subsequently embedded in $2 \%$ agar and washed three times in sodium cacodylate. Post-fixation was carried out in cacodylate buffered $0.5 \% \mathrm{OsO}_{4}$ solution for $1 \mathrm{~h}$. After staining with uranyl acetate $(1 \%$ in distilled water, $30 \mathrm{~min}$ ) the samples were dehydrated in a graded ethanol series $(50,70,90,96,100 \%)$ followed by propylene oxide and embedded in Durcupan (Fluka). After polymerization the resin-embedded samples were cut with a Reichert ultramicrotome, the sections stained with lead-citrate and examined in a JEM100CX II microscope (JEOL).

Physiological and biochemical characterization. Growth in the presence of oxygen was tested using slant agar cultures on King B medium incubated in an anaerobic chamber (Forma Scientific). Oxidase activity was checked by the method of Tarrand \& Gröschel (1982), and catalase production and Voges-Proskauer reaction were demonstrated by the standard methods of Cowan \& Steel (1974). Growth on synthetic medium was tested by using the medium of Droop (1969) and on semi-synthetic medium using PCa agar (containing $2 \mathrm{~g}$ peptone, $0 \cdot 2 \mathrm{~g} \mathrm{MgSO}_{4} .7 \mathrm{H}_{2} \mathrm{O}, 0 \cdot 15 \mathrm{~g} \mathrm{CaCl}_{2}$ ). Acid production from different carbohydrates was studied by the OF test according to Hugh \& Leifson (1953) and using API CH50 test strips (CHE inoculation fluid; bioMérieux). Growth at different temperatures $(4,28,37$ and $\left.45^{\circ} \mathrm{C}\right), \mathrm{NaCl}$ tolerance $(2.5$ and $5 \%, \mathrm{w} / \mathrm{v})$ and $\mathrm{pH}$ tolerance $(2,4,6,8,9,10$ and 11) were determined using King $\mathrm{B}$ agar or broth. Urease activity, reduction of $\mathrm{NO}_{3}^{-}$, aesculin and starch hydrolysis, indole production from tryptophan, casease, gelatinase, phosphatase activity and $\mathrm{H}_{2} \mathrm{~S}$ production from cysteine were studied according to Smibert \& Krieg (1994). Haemolysin production was tested on ox-blood agar plates (Elek \& Levy, 1954). Utilization of citrate was checked according to Simmons (1926) and hydrolysis of chitin was studied by the modified method of Holding \& Collee (1971) (instead of a nutrient basal medium, King B agar was used). Utilization of 95 different carbon sources as sole carbon source was studied on BIOLOG GNplates. To evaluate the results System Release 3.5 was used, following the manufacturer's instructions. Mannose and arabinose utilization as sole carbon source was tested according to Gordon \& Mihm (1957). Acetylene reduction activity was studied with capped cultures of bacteria grown on semisolid RBA medium (DSMZ-Medium 441) without yeast extract. One-tenth volume of acetylene was added to the atmosphere 36 hours after inoculation and the amount of ethylene was measured immediately after the addition of acetylene, then 3, 6, 12 and $24 \mathrm{~h}$ later using a Hewlett Packard 5890A gas chromatograph equipped with a flame ionization detector and a packed metal column $[6 \mathrm{ft} \times 1 / 8$ in $(1.83 \mathrm{~m} \times 3.2 \mathrm{~mm})$ stainless steel, $80 / 100$ HayeSepN]. The flow rate of the carrier gas (nitrogen) was $20 \mathrm{ml} \mathrm{min}$. Injector, column and detector temperatures were 100,100 and $165^{\circ} \mathrm{C}$, respectively (Hardy et al., 1973).

Chemotaxonomic characterization. Cells for chemotaxonomic analysis were grown in liquid Rich medium (Yamada $\&$ Komagata, 1972) to the middle of their exponential phase on a rotary shaker at $28{ }^{\circ} \mathrm{C}$. Isoprenoid quinones were extracted as described by Collins et al. (1977) and the profile was analysed by HPLC (Groth et al., 1997). Cellular fatty acids were extracted according to Stead et al. (1992) and analysed by GC (Groth et al., 1996). Polar lipids were determined according to the method described by Minnikin et al. (1979).

Determination of the $\mathbf{G}+\mathbf{C}$ content of DNA. DNA was isolated and its $\mathrm{G}+\mathrm{C}$ content was determined by HPLC analysis of derived deoxyribonucleosides as described by Groth et al. (1996).

DNA-DNA hybridization. DNA-DNA hybridizations between each of the four strains were performed as described by Maszenan et al. (1999).

16S rDNA sequence determination and phylogenetic analysis. Genomic DNA extraction and PCR-mediated amplification of the 16S rDNA of the selected bacterial strains were carried out by the method of Rainey et al. (1996). The amplified PCR products were purified and concentrated by using a Prep-A-Gene kit (Bio-Rad). Cycle sequencing was performed in a Gene-Amp 2400 PCR machine (Perkin Elmer) with the Big Dye Terminator Cycle Sequencing kit, according to the protocol of the manufacturer. Base sequences were determined in an Applied Biosystems model 310 Genetic Analyser (Perkin Elmer). The 16S rDNA sequences of L1/68 ${ }^{\mathrm{T}}, \mathrm{L} 157, \mathrm{~L} 1 / 58$ and L2/11 were aligned against the ARB-formatted RDP Release 7.1 (Maidak et al., 1997) using the ARB programme package (Strunk \& Ludwig, 1995). To check for more recent updates an additional BLAST search (Altschul et al., 1997) was also performed. The methods of Jukes \& Cantor (1969) and the Kimura 2-parameter method were used to calculate evolutionary distances. Phylogenetic analysis was carried out applying various treeing algorithms (neighbour-joining , maximum-likelihood, parsimony and DeSote tree fit) integrated into the ARB program. The consensus phylogenetic dendrogram was reconstructed from Jukes-Cantor evolutionary distances based on the neighbour-joining method using Bacillus subtilis as root.

Nucleotide accession numbers. The strain designations and accession numbers of nucleotide sequences used in the phylogenetic analyses are as follows: Bacillus subtilis D26185, Cardiobacterium hominis ATCC 15826 ${ }^{\mathrm{T}}$, M35014; Comamonas testosteroni ATCC 11996 ${ }^{\mathrm{T}}$, M11224; Desulfovibrio desulfuricans ATCC 27774 ${ }^{\mathrm{T}}$, M34113; Escherichia coli K-12, U00096; Frateuria aurantia IFO 3245 , AJ010481; Lysobacter antibioticus DSM 2077 ${ }^{\mathrm{T}}$, AB019582; Proteus vulgaris IFAM 1731, X07652; Rhodanobacter lindaniclasticus LMG 18385" , AF039167; Rhodospirillum rubrum, X87278; Sphingomonas paucimobilis ATCC $29837^{\mathrm{T}}$, 
U37337; Stenotrophomonas maltophilia LMG 958 ${ }^{\mathrm{T}}$, X95923; Suttonella indologenes ATCC 25869 ${ }^{\mathrm{T}}$, M35015; Wolinella succinogenes ATCC 29543 ${ }^{\mathrm{T}}$, M88159; Xanthomonas campestris LMG 568 , X95917; Xylella fastidiosa ATCC 35871, AF203388; Xylella fastidiosa ATCC 35879 , AF203391.

\section{RESULTS}

\section{Culture characteristics and colony morphology}

Growth of the bacterial strains isolated from the larvae of Wohlfahrtia magnifica was optimal on King B agar medium under aerobic conditions, while growth was weak on the semi-synthetic PCa medium and no growth appeared on synthetic medium (Droop, 1969). Isolates did not grow on media containing mannose or arabinose as sole carbon source (Gordon \& Mihm, 1957), although the utilization of the aforementioned carbon sources on the BIOLOG microplate was

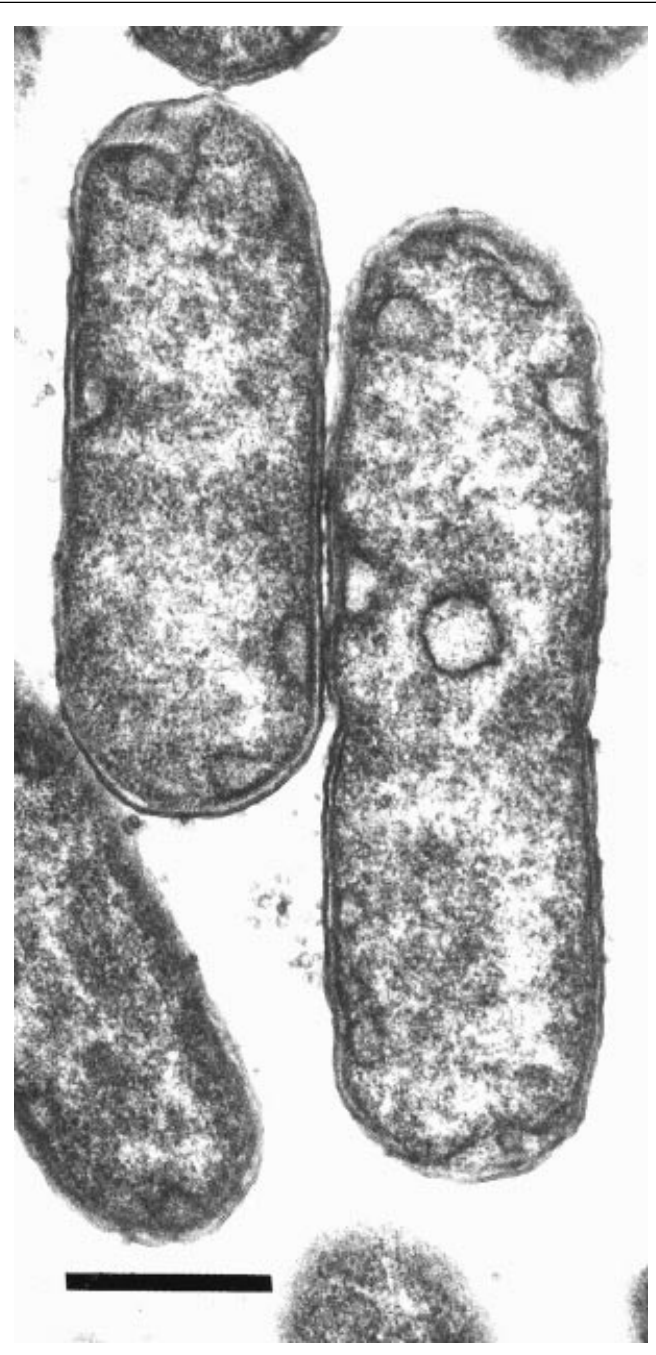

Fig. 1. Longitudinal section of bacteria from strain $L 1 / 68^{\top}$ as depicted by TEM. Cells are regularly rod-shaped with typical Gram-negative cell wall structure. Note invaginations of the inner membrane and the ring-like structure in the longer cell. Bar, $0.5 \mu \mathrm{m}$.

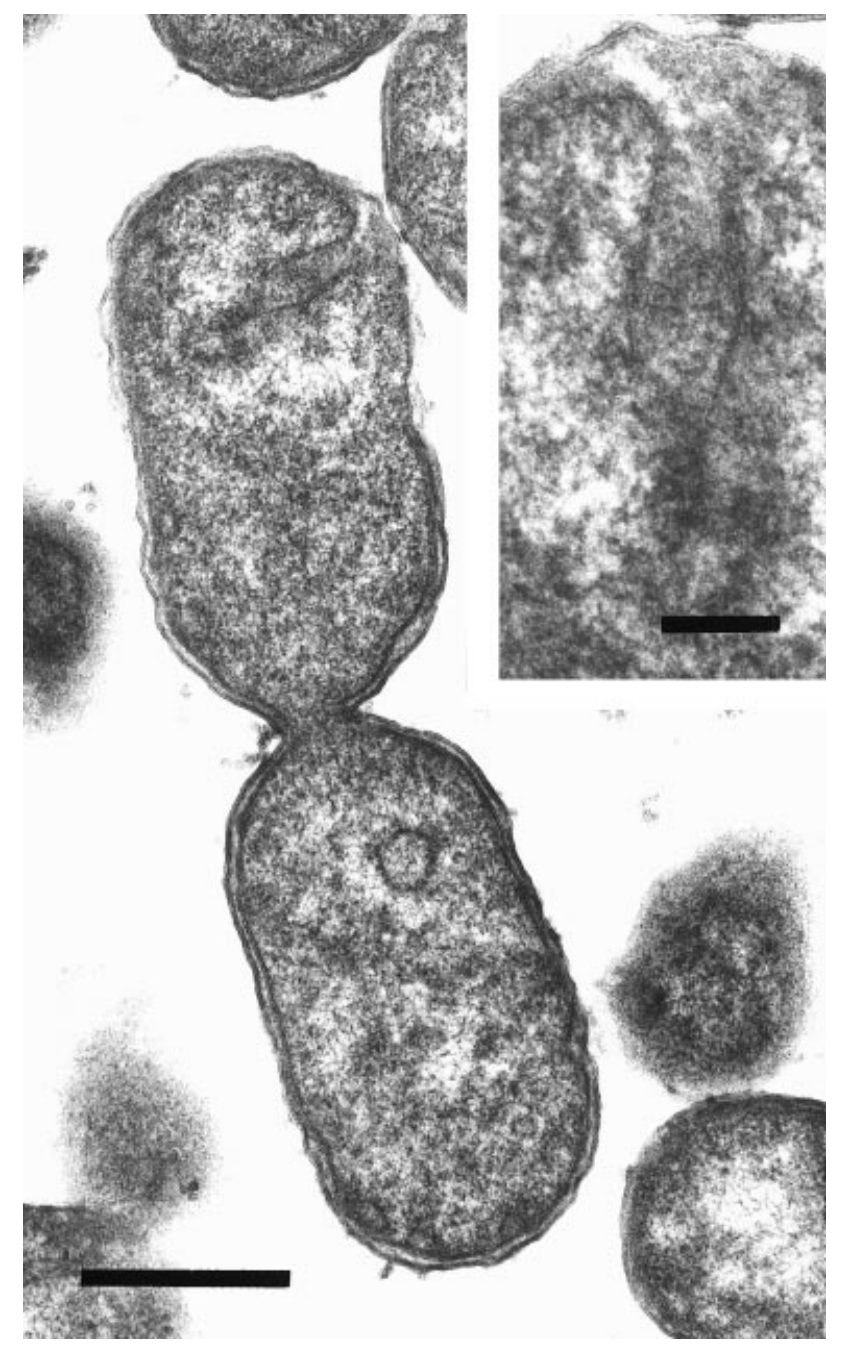

Fig. 2. Transmission electron micrograph of a dividing strain $\mathrm{L} 1 / 68^{\top}$ cell. Note the deep invagination in the upper and ringlike structure in the lower daughter cell. Bar, $0.5 \mu \mathrm{m}$. The insert clearly shows that the inner membrane is continuous with the membrane of the invagination. Bar, $0 \cdot 1 \mu \mathrm{m}$.

Table 1 Differences in the main biochemical and physiological characteristics of Wohlfahrtia strains

+ , Positive reaction; - , negative reaction; \pm , weak reaction; +++ , strong reaction.

\begin{tabular}{|lcccc|}
\hline Characteristic & L1/68 $^{\mathbf{T}}$ & $\mathbf{L 1 / 5 7}$ & $\mathbf{L 1 / 5 8}$ & $\mathbf{L 2 / 1 1}$ \\
\hline Oxidase & + & + & - & + \\
Catalase & \pm & + & \pm & + \\
Growth at: & & & & \\
$\quad 4{ }^{\circ} \mathrm{C}$ & \pm & + & \pm & + \\
$45^{\circ} \mathrm{C}$ & \pm & + & + & + \\
Phosphatase & + & + & \pm & + \\
$\mathrm{H}_{2} \mathrm{~S}$ from cysteine & \pm & + & + & + \\
Tween 80 hydrolysis & - & \pm & - & - \\
Chitinase activity & +++ & + & + & +++ \\
\hline
\end{tabular}




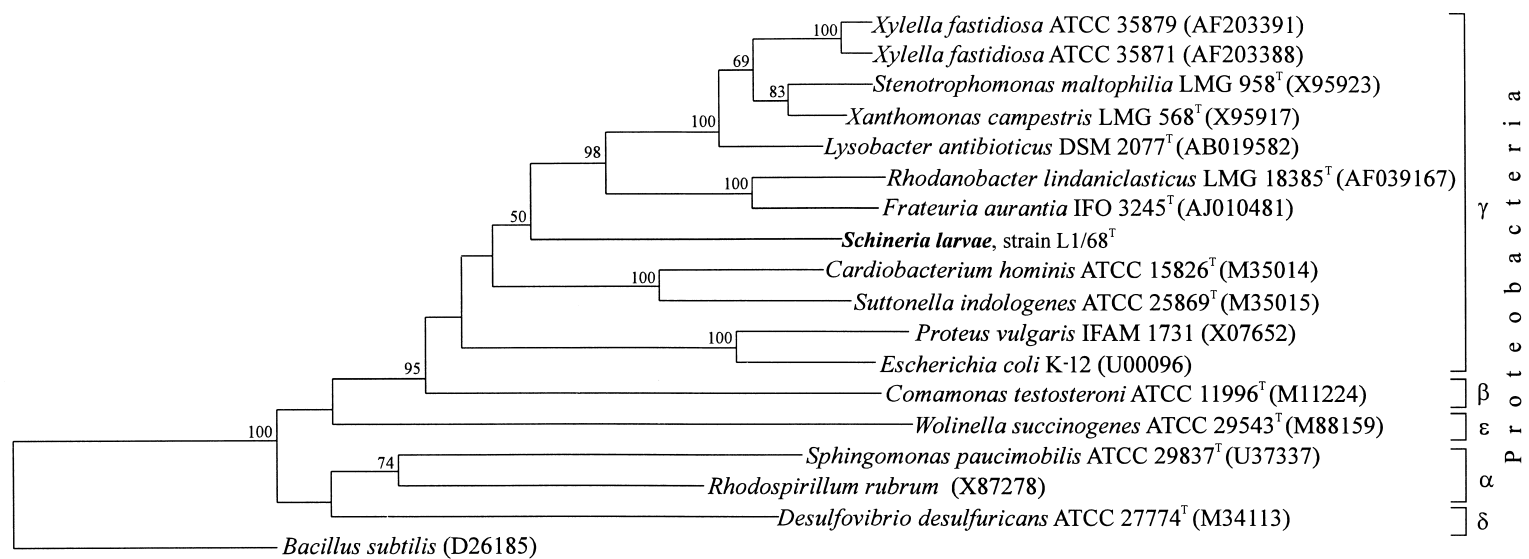

0.10

Fig. 3. Phylogenetic position of Schineria larvae strain $L 1 / 68^{\top}$ within the Xanthomonas-Rhodanobacter lineage of the $\gamma$-Proteobacteria (Jukes-Cantor evolutionary distance calculation, neighbour-joining tree). Bar represents $10 \mathrm{nt}$ substitutions per $100 \mathrm{bp}$. Bootstrap values (based on 100 steps) lower than $50 \%$ are not indicated.

variable among the examined strains. All strains formed bright, easily spreadable, entire, convex, translucent, small colonies (1-3 mm diameter) on the surface of King B agar medium. No distinctive colony colour or diffusible pigments were observed.

\section{Cell morphology, staining properties and ultrastructure}

On King B medium 24-h-old cultures of strains $\mathrm{L} 1 / 68^{\mathrm{T}}, \mathrm{L} 1 / 57, \mathrm{~L} 1 / 58$ and $\mathrm{L} 2 / 11$ were composed of regular rods $(2-3 \mu \mathrm{m} \times 0.8-0.9 \mu \mathrm{m})$ occurring singly. In ageing cultures ( $48 \mathrm{~h}-1$ week) no characteristic shape shifts were detected. Cells stained Gram-negative and were non-motile. Endospores were not formed. Capsules were detected. Electron micrographs of thin sections of strain L1/68 ${ }^{\mathrm{T}}$ are shown in Figs 1 and 2. The regular cell shape is evident from Fig. 1, depicting the typical Gram-negative cell wall structure. Notable features of the cells are invaginations of the inner membrane (Fig. 1). Some of the invaginations in appropriate sections may appear as finger-like intrusions. Fig. 2 and the insert clearly show that the membrane of a deep invagination is continuous with the cytoplasmic membrane. The frequently occurring ring-like structures (Figs 1 and 2) are most likely to be cross sections of the finger-like intrusions.

\section{Physiological and biochemical characteristics}

Bacterial strains $\mathrm{L} 1 / 68^{\mathrm{T}}, \mathrm{L} 1 / 57, \mathrm{~L} 1 / 58$ and $\mathrm{L} 2 / 11$ grew under strictly aerobic conditions. No growth was detected under anaerobic conditions, even in the presence of $\mathrm{NO}_{3}^{-}$as terminal electron acceptor. Catalase reaction was positive and oxidase reaction was also positive except for strain $\mathrm{L} 1 / 58$. Temperature range for cell growth on King B agar medium was between 4 and $45^{\circ} \mathrm{C}$ showing an optimum between 28 and $37^{\circ} \mathrm{C}$. All four strains grew between $\mathrm{pH} 6.0$ and
$10 \cdot 0$ but they preferred slightly alkaline $\mathrm{pH}(7 \cdot 5-9 \cdot 0)$. All strains examined were negative for Simmons' citrate, aesculin, Voges-Proskauer, indole, starch, casease, gelatinase and haemolysis but positive for phosphatase, urease and $\mathrm{H}_{2} \mathrm{~S}$. All strains had strong chitinase activity compared to the other chitin-utilizing bacteria isolated from fly larvae and chitin-utilizing moulds isolated from soil (Paecylomyces fumosoroseus and Beauveria bassiana). The hydrolysis of Tween 80 proved to be negative in all strains except strain L1/57, where a weakly positive reaction could be detected. This latter trait was also proven by the results of Tween 80 utilization as sole carbon source in the BIOLOG GN test. Differences in the basic biochemical characteristics of the strains are summarized in Table 1. The results of utilization of different sole carbon sources showed that there were 22 different carbon sources which always gave negative reactions in all strains $(\alpha$-cyclodextrin, glycogen, D-arabitol, cellobiose, i-erythritol, gentiobiose, $\alpha$-D-lactose, $\alpha$-Dlactose-lactulose, xylitol, D-galacturonic acid lactone, D-glucosaminic acid, $\alpha$-ketovaleric acid, propionic acid, quinic acid, D-saccharic acid, sebacic acid, Lthreonine, DL-carnitine, phenylethylamine, putrescine, 2-amino-ethanol and 2,3-butanediol). In the case of 14 carbon sources (monomethylsuccinate, cis-aconitic acid, citric acid, $\gamma$-hydroxybutyric acid, $\alpha$-ketoglutaric acid, succinic acid, L-asparagine, L-glutamic acid, glycyl-L-glutamic acid, L-histidine, L-leucine, Lphenylalanine, L-pyroglutamic acid and $\gamma$-aminobutyric acid) all strains showed a positive reaction. Utilization of 59 other sole carbon sources varied among the strains examined (dextrin, Tween 40, Tween 80, $\mathrm{N}$-acetyl-D-galactosamine, adonitol, L-arabinose, D-fucose, L-fucose, D-galactose, $\alpha$-D-glucose, $m$-inositol, maltose, D-mannitol, D-mannose, D-melibiose, $\beta$-methyl-D-glucoside, D-psicose, D-raffinose, Lrhamnose, D-sorbitol, sucrose, D-trehalose, turanose, 
Table 2 Fatty acid composition of the bacterial strains

\begin{tabular}{|ccccccccc|}
\hline Strain & \multicolumn{7}{c|}{ Fatty acid composition (\%) } \\
\cline { 2 - 8 } & $\mathbf{C}_{\mathbf{1 4 : 0}}$ & $\mathbf{C}_{\mathbf{1 6 : 0}}$ & $\mathbf{C}_{\mathbf{1 8}}$ & $\mathbf{C}_{\mathbf{1 6 : 1}}$ & $\mathbf{C}_{\mathbf{1 8 : 1}}$ & $\begin{array}{c}\mathbf{3 O H}- \\
\mathbf{C}_{\mathbf{1 2 : 0}}\end{array}$ & $\mathbf{3 O H}_{\mathbf{1 4 : 0}}$ & $\begin{array}{c}\mathbf{C y c l o} \\
\mathbf{C}_{\mathbf{1 8 : 0}}\end{array}$ \\
\hline $\mathrm{Lt} / 68^{\mathrm{T}}$ & $20 \cdot 1$ & $23 \cdot 1$ & $0 \cdot 6$ & $2 \cdot 8$ & $30 \cdot 7$ & $2 \cdot 8$ & $6 \cdot 0$ & $8 \cdot 9$ \\
$\mathrm{~L} 1 / 58$ & $18 \cdot 3$ & $25 \cdot 9$ & $0 \cdot 7$ & $3 \cdot 0$ & $33 \cdot 7$ & $6 \cdot 9$ & $4 \cdot 4$ & $3 \cdot 3$ \\
L1/57 & $17 \cdot 7$ & $22 \cdot 9$ & $1 \cdot 1$ & $3 \cdot 1$ & $36 \cdot 9$ & $6 \cdot 4$ & $4 \cdot 2$ & $3 \cdot 9$ \\
L2/11 & $22 \cdot 5$ & $21 \cdot 2$ & - & $2 \cdot 7$ & $35 \cdot 1$ & $9 \cdot 0$ & $5 \cdot 1$ & $4 \cdot 6$ \\
\hline
\end{tabular}

methylpyruvate, acetic acid, formic acid, D-galacturonic acid lactone, D-gluconic acid, D-glucuronic acid, $\alpha$-hydroxybutyric acid, $\beta$-hydroxybutyric acid, $p$ hydroxyphenylacetic acid, itaconic acid, $\alpha$-ketobutyric acid, DL-lactic acid, malonic acid, bromosuccinic acid, succinamic acid, glucuronamide, alaninamide, Dalanine, L-alanine, L-alanyl-glycine, L-aspartic acid, hydroxy-L-proline, L-ornithine, L-proline, D-serine, Lserine, urocanic acid, inosine, uridine, thymidine, glycerol, DL-glycerol phosphate, glucose 1-phosphate, glucose 6-phosphate). Some strains lost the ability to utilize some carbon sources after 2 years of maintenance in the laboratory. Using the API CH50 system acid production was negative in all cases. No nitrogenase activity could be detected, although the strains grew slightly on RBA medium.

\section{Phylogenetic analysis}

The results of the phylogenetic analysis are shown in Fig. 3. (Jukes-Cantor phylogenetic distance calculations, neighbour-joining treeing). Almost complete 16S rDNA sequences of strains L1/68 ${ }^{\mathrm{T}}, \mathrm{L} 1 / 57, \mathrm{~L} 1 / 58$ and L2/11, composed of 1514, 1514, 1523 and 1518 bp, respectively ( $>98 \%$ of the complete E. coli sequence; Brosius et al., 1978), were used for analysis. All isolates were completely identical to each other. The highest similarity values were found with members of the Xanthomonas-Rhodanobacter assemblages within the $\gamma$-subclass of the Proteobacteria. Similarity ranks for the nearest neighbours of the XanthomonasRhodanobacter line were not significantly different (Xylella fastidiosa ATCC 35871, 86.57\% ; Lysobacter antibioticus, 86.7\%; Frateuria aurantia, 86.3\%; Rhodanobacter lindaniclasticus, $85.8 \%$; Cardiobacterium hominis, $85.7 \%$; Xanthomonas campestris, $86.5 \%$; Stenotrophomonas maltophilia, 86.9\%), although Xylella fastidiosa ATCC 35879 proved to be the closest relative $(87 \cdot 1 \%)$. Similarities to representatives of other subclasses of Proteobacteria were also determined: Rhodospirillum rubrum (80.7\%), Comamonas testosteroni ( $82.9 \%)$, Desulfovibrio desulfuricans $(79 \cdot 3 \%)$ and Wolinella succinogenes $(79 \cdot 1 \%)$. Similar tree topology was achieved using Jukes-Cantor distance calculations with neighbour-joining and maximum-likelihood treeing and Kimura 2parameter/neighbour-joining tree generation; how- ever, the bootstrap value on the position of Schineria larvae was only $50 \%$. The position of Schineria larvae within the Rhodanobacter-Xanthomonas assemblage of the $\gamma$-Proteobacteria was practically the same using parsimony and De Soete tree fit algorithms.

\section{Chemotaxonomic characterization}

Since all strains proved to have identical 16S rDNAs only the fatty acid profiles were examined in all strains, and strain L1/68 $8^{\mathrm{T}}$ was studied in detail chemotaxonomically. The $\mathrm{G}+\mathrm{C}$ content of DNA of this strain was $42 \mathrm{~mol} \%$. The predominant respiratory quinone was Q-8, while Q-7 and Q-5 could be detected as minor components. It contained phosphatidylglycerol (PG) and diphosphatidylglycerol (DPG; minor amounts), phosphatidylethanolamine (PE), phosphatidylserine (PS) and two unknown polar lipids. The fatty acid profiles of the four strains are reported in Table 2.

\section{DNA-DNA hybridization}

At the DNA level the four examined strains are quite similar as their similarity values demonstrate: $\mathrm{L} 1 / 57$ to $\mathrm{L} 1 / 58,98.9 \% ; \mathrm{L} 1 / 57$ to $\mathrm{L} 2 / 11,102.5 \% ; \mathrm{L} 1 / 57$ to $\mathrm{L} 1 / 68^{\mathrm{T}}, 98 \cdot 6 \% ; \mathrm{L} 1 / 58$ to $\mathrm{L} 1 / 68^{\mathrm{T}}, 99 \cdot 4 \% ; \mathrm{L} 2 / 11$ to $\mathrm{L} 1 / 68^{\mathrm{T}}, 97 \cdot 8 \%$.

\section{DISCUSSION}

Although all developmental stages of Wohlfahrtia magnifica and bacterial communities of fly-infested wounds were tested for their bacterial partners, bacteria belonging to this lineage of $\gamma$-Proteobacteria were detected only in the 1st and 2nd larval stage samples (Tóth et al., 1998). It is interesting to note, however, that the strains examined originating from different specimens of different larval stages of Wohlfahrtia magnifica are totally identical with regard to their $16 \mathrm{~S}$ rDNA and their DNA-DNA hybridization values are similarly high. At the same time extremely high variations could be detected in the utilization of carbon sources: among 95 examined, only 36 (39\%) were uniform at different times of testing. The ability to utilize other carbon sources disappeared or became positive during the 2 years of investigation. It can be speculated that some of these traits were encoded on 
plasmids and subsequently lost due to subculturing under non-selective pressure.

The temperature range for growth of the strains is not surprising as the larvae grow in the live tissue of warmblooded animals, where the temperature is usually between 35 and $38^{\circ} \mathrm{C}$. The observation that these bacteria preferred a slightly alkaline $\mathrm{pH}$ may result from the feeding habit of the fly larvae on tissues of sheep where the $\mathrm{pH}$ is alkaline, due to ammonification performed by a diverse population of wound bacteria (Guerrini et al., 1988; Khoga, 1994). Based on the strong chitinase activity of the strains we can speculate that these bacteria may play a significant role in the metamorphosis of the fly as reported for some Pseudomonas species which have an important function in the moulting of the screwworm Cochliomyia hominivorax by their chitinase enzyme production (Gassner et al., 1983). The slow growth of strains on diazotrophic medium (RBA) indicates that a low nitrogen supply is adequate for reproduction of these bacteria (though the fly larvae live in a nitrogen-rich environment).

Based upon the distinct phylogenetic position a new genus is proposed for the Wohlfahrtia magnifica isolates. Low similarity values to related species and the phylogenetic dendrogram shown in Fig. 3 indicate that the isolates represent a new genus as a deeply rooting lineage next to the RhodanobacterLysobacter-Xylella assemblage within the $\gamma$-Proteobacteria. The base $\mathrm{G}+\mathrm{C}$ content of the 16S rDNA of the isolates is $42 \mathrm{~mol} \%$ which is not close to the values determined for Xylella (53 mol\%), Rhodanobacter (63 $\mathrm{mol} \%$ ) and Lysobacter (66 mol\%), but our strains are located far from their closest known relatives.

The affiliation of the isolates to the $\gamma$-Proteobacteria is supported by the presence of three signature nucleotides in the 16S rDNA $(976,1233$ and $1234-\mathrm{G}, \mathrm{G}$ and $\mathrm{C}$ respectively; Woese, 1987) distinguishing the members of the $\gamma$ - and $\beta$-subclasses. Furthermore, the presence of ubiquinone Q-8 confirms the membership of the $\gamma$-subclass (Collins \& Jones, 1981).

All strains are identical in their 16S rDNA sequence and highly similar in biochemical and physiological properties. Their fatty acid composition is quite similar and their hybridization values to each other are also high. As they cannot be differentiated unambiguously by the carbon source utilization tests, we consider these strains as a single species.

\section{Description of Schineria gen. nov.}

Schineria (shi'ner.i.a. N.L. fem. gen. n. Schineria pertaining to Schiner who first described the fly Wohlfahrtia magnifica in 1862).

Cells are Gram-negative regular rods. Non-motile, endospores are not formed. Capsules may be produced. Aerobic. Catalase reaction is positive (occasionally weak), oxidase reaction is variable. Main fatty acids are $\mathrm{C}_{18: 1}, \mathrm{C}_{16: 0}$ and $\mathrm{C}_{14: 0}$, main polar lipids are PG, DPG, PS and PE. Predominant respiratory quinone is Q-8. $\mathrm{G}+\mathrm{C}$ content of DNA is $42 \mathrm{~mol} \%$.
Phylogenetically a member of the $\gamma$-subclass of the Proteobacteria. Unequivocal affiliation by primary structure of $16 \mathrm{~S}$ rDNA. The type species is Schineria larvae.

\section{Description of Schineria larvae sp. nov.}

Schineria larvae (lar'vae. L. gen. fem. larvae pertaining to the origin of the type strain isolated from Wohlfahrtia magnifica maggots).

Cells are straight, short, single rods $(2-3 \mu \mathrm{m} \times 0 \cdot 8$ $0.9 \mu \mathrm{m})$, non-motile and encapsulated, occurring singly at all ages. On agar media colonies are nonpigmented, small (1-3 mm in diameter), circular with entire margin and smooth surface. Strictly aerobic, $\mathrm{NO}_{3}^{-}$not reduced. Optimum growth occurs between $\mathrm{pH} 6$ and 10 . Temperature range is wide $\left(4-45^{\circ} \mathrm{C}\right)$, optimum growth at $28-37^{\circ} \mathrm{C}$. Catalase-positive, oxidase-variable. Urea and chitin are hydrolysed. Indole, casein and gelatin are not metabolized. $\mathrm{H}_{2} \mathrm{~S}$ is produced from cysteine. Simmon's citrate, VogesProskauer and aesculin digestion are negative. Not haemolytic. Uses monomethylsuccinate, cis-aconitic acid, citric acid, $\gamma$-hydroxybutyric acid, $\alpha$-ketoglutaric acid, succinic acid, L-asparagine, L-glutamic acid, glycyl-L-glutamic acid, L-histidine, L-leucine, Lphenylalanine, L-pyroglutamic acid and $\gamma$-aminobutyric acid as sole carbon source. No utilization of $\alpha$ cyclodextrin, glycogen, D-arabitol, cellobiose, i-erythritol, gentiobiose, $\alpha$-lactose, $\alpha$-D-lactose-lactulose, xylitol, D-galacturonic acid lactone, D-glucosaminic acid, $\alpha$-ketovaleric acid, propionic acid, quinic acid, Dsaccharic acid, sebaic acid, L-threonine, DL-carnitine, phenylethylamine, putrescine, 2-aminoethanol and 2,3-butanediol. No acid production from carbohydrates in API CH50. The major isoprenoid quinone is Q-8. The major fatty acids are $\mathrm{C}_{18: 1}, \mathrm{C}_{16: 0}$ and $\mathrm{C}_{14: 0}$. Cyclo- $\mathrm{C}_{18: 0}$ also occurs. Predominant polar lipids are PG, PE and PS. G $+C$ content of DNA is $42 \mathrm{~mol} \%$. Isolated from the L1 and L2 stage larvae of an obligate parasitic fly, Wohlfahrtia magnifica. Type strain is $\mathrm{L} 1 / 68^{\mathrm{T}}\left(=\mathrm{DSM} 13226^{\mathrm{T}}=\right.$ NCAIM B01938 $\left.{ }^{\mathrm{T}}\right)$.

\section{ACKNOWLEDGEMENTS}

This work was supported by grants from OTKA (No. T026599) and FKFP (No. 0537), which are gratefully acknowledged.

\section{REFERENCES}

Altschul, S. F., Madden, T. L., Schäffel, A. A., Zhang, J., Zhang, Z., Miller, W. \& Lipmann, D. J. (1997). Gapped BLAST and PSI-BLAST: a new generation of protein database search programs. Nucleic Acids Res 25, 3389-3402.

Brosius, J., Palmer, M. L., Kennedy, P. J. \& Noller, H. F. (1978). Complete nucleotide sequence of a $16 \mathrm{~S}$ ribosomal RNA gene from Escherichia coli. Proc Natl Acad Sci U S A 75, 4801-4805.

Cazemier, A. E., Hackstein, J. H. P., Op den Camp, H. J. M., Rosenberg, J. \& van der Drift, C. (1997). Bacteria in the intestinal tract of different species of arthropods. Microb Ecol 33, 189-197. 
Claus, M. (1992). A standardised Gram staining procedure. World J Microbiol Biotechnol 8, 451-452.

Collins, M. \& Jones, D. (1981). Distribution of isoprenoid quinone structural types in bacteria and their taxonomic implications. Microbiol Rev 45, 316-354.

Collins, M. D., Pirouz, T., Goodfellow, M. \& Minnikin, D. E. (1977). Distribution of menaquinones in actinomycetes and corynebacteria. J Gen Microbiol 100, 221-230.

Cowan, S. T. \& Steel, K. J. (1974). Manual for Identification of Medical Bacteria. Cambridge: Cambridge University Press.

Cruden, D. L. \& Markovetz, A. J. (1984). Microbial aspects of the cockroach hindgut. Arch Microbiol 138, 131-139.

Droop, M. R. (1969). Algae. Methods Microbiol 2, 574-575.

Duguid, J. P. (1951). The demonstration of bacterial capsules and slime. J Pathol Bacteriol 63, 673.

Elek, S. D. \& Levy, E. (1954). The nature of discrepancies between haemolysins in culture filtrates and plate haemolysin patterns of staphylococci. J Pathol Bacteriol 60, 31-34.

Farkas, R., Hall, M. J. R. \& Kelemen, F. (1997). Wound myiasis of sheep in Hungary. Vet Parasitol 69, 133-144.

Gassner, G., Duh, F. M. \& Bromel, M. (1983). Chitinolytic activity: a prelude to a symbiotic relationship between bacteria and the screwworm fly. Endocytobiology 2, 801-807.

Gordon, R. E. \& Mihm, J. M. (1957). A comparative study of some strains received as nocardiae. J Bacteriol 73, 15-17.

Groombridge, B. (1992). Global Biodiversity, Status of Earth's Living Resources. London: Academic Press.

Groth, I., Schumann, P., Weiss, N., Martin, K. \& Rainey, F. A. (1996). Agrococcus jenensis gen. nov., sp. nov., a new genus of actinomycetes with diaminobutyric acid in the cell wall. Int $J$ Syst Bacteriol 46, 234-239.

Groth, I., Schumann, P., Rainey, F. A., Martin, K., Schuetze, B. \& Augsten, K. (1997). Demetria terragena gen. nov., sp. nov., a new genus of actinomycetes isolated from compost soil. Int J Syst Bacteriol 47, 1129-1133.

Guerrini, V. H., Murphy, G. M. \& Broadmeadow, M. (1988). The role of $\mathrm{pH}$ in the infestation of sheep by Lucilia cuprina larvae. Int $J$ Parasitol 18, 407-409.

Hall, M. J. (1997). Traumatic myiasis of sheep in Europe: a review. Parasitologia 39, 409-413.

Hall, M. J. R. \& Wall, R. (1995). Myiasis of humans and domestic animals. Adv Parasitol 35, 257-337.

Hardy, R. W., Burns, R. C. \& Holsten, R. D. (1973). Applications for the acetylene-ethylene assay for measurement of nitrogen fixation. Soil Biol 5, 47-81.

Holding, A. J. \& Collee, J. G. (1971). Routine biochemical tests. Methods Microbiol 6A, 1-7.

Hugh, R. \& Leifson, E. (1953). The taxonomic significance of fermentative versus oxidative metabolism of carbohydrates by Gram negative bacteria. J Bacteriol 66, 24-26.

Ishikawa, H. (1989). A synthesis: the types of interaction system between bacteria and insects. Endocytobiology 4, 355-361.

Jukes, T. H. \& Cantor, C. R. (1969). Evolution of protein molecules. In Mammalian Protein Metabolism, pp. 21-132. Edited by H. N. Munro. New York: Academic Press.

King, E. O., Ward, M. K. \& Raney, D. E. (1954). Two simple media for the demonstration of pyocyanin and fluorescein. $J$ Lab Clin Med 44, 301-302.
Khoga, J. (1994). Myiasis: a consequence or a cause of skin bacterial alterations. $\mathrm{PhD}$ thesis, Budapest.

Maidak, B. L., Olsen, G. J., Larsen, N., Overbeek, R., McCaughey, M. J. \& Woese, C. R. (1997). The RDP (Ribosomal Database Project). Nucleic Acids Res 25, 109-111.

Martinez, R. I., Cruz, S. M. D., Rodriguez, R. B., Lopez, D. M., Parra, M. S. \& Navio, S. A. (1987). Myiasis caused by Wohlfahrtia magnifica in Southern Spain. Isr J Vet Med 43, 34-41.

Martinez, R. I., Cruz, S. M. D., Rodriguez, R. B, Jimenez, J. M. P. \& Lopez, M. D. (1991). Myiasis caused by Wohlfahrtia magnifica in sheep and goats in Southern Spain II. Effect of age, body region and sex on larval infestation. Isr J Vet Med 46, 44-47.

Maszenan, A. M., Seviour, R. J., Patel, B. K. C., Schumann, P., Burghardt, J., Webb, R. I., Soddell, J. A. \& Rees, G. N. (1999). Friedmanella spumicola sp. nov. and Friedmanella capsulata sp. nov. from activated sludge foam: Gram positive cocci that grow in aggregates of repeating groups of cocci. Int $J$ Syst Bacteriol 49, 1667-1680.

Minnikin, D. E., Collins, M. D. \& Goodfellow, M. (1979). Fatty acid and polar lipid composition in the classification of Cellulomonas, Oerskovia and related taxa. J Appl Bacteriol 47, 87-95.

Rainey, F. A., Rainey, W. N., Kroppenstedt, R. M. \& Stackebrandt, E. (1996). The genus Nocardiopsis represents a phylogenetically coherent taxon and a distinct actinomycete lineage: proposal of Nocardiopsaceae fam. nov. Int J Syst Bacteriol 46, 1088-1092. Schiner, L. (1862). Sarcophyla magnifica. Fauna Aust I, 567-568. Simmons, J. S. (1926). A culture medium for differentiating organisms of typhoid colon aerogenes groups and for isolation of certain fungi. J Infect Dis 39, 209-211.

Smibert, R. M. \& Krieg, N. R. (1994). Phenotypic characterisation. In Methods for General and Molecular Bacteriology, pp. 603-711. Edited by P. Gerhardt, R. G. E. Murray, W. A. Wood \& N. R. Krieg. Washington, DC: American Society for Microbiology.

Stead, D. E., Sellwood, J. E., Wilson, J. \& Viney, I. (1992). Evaluation of a commercial microbial identification system based on fatty acid profiles for rapid, accurate identification of plant pathogenic bacteria. J Appl Bacteriol 72, 315-321.

Strunk, O. \& Ludwig, W. (1995). ARB - a software environment for sequence data. Department of Microbiology, Technical University of Munich, Germany.

Tanada, Y. \& Kaya, H. K. (1993). Insect Pathology. New York: Academic Press.

Tarrand, J. J. \& Gröschel, D. H. M. (1982). Rapid, modified oxidase test for oxidase-variable bacterial isolates. $J$ Clin Microbiol 16, 772-774.

Tóth, E., Farkas, R., Márialigeti, K. \& Mokhtar, I. S. (1998). Bacteriological investigations on wound myiasis of sheep caused by Wohlfahrtia magnifica (Diptera: Sarcophagidae). Acta Vet Hung 46, 219-229.

Valentin, A., Baumann, M. P, Schein, E. \& Bajanbileg, S. (1997). Genital myiasis (wohlfahrtiosis) in camel herds of Mongolia. Vet Parasitol 73, 335-346.

Yamada, K. \& Komagata, K. (1972). Taxonomic studies on coryneform bacteria. IV. Morphological, cultural, biochemical, and physiological characteristics. J Gen Appl Microbiol 18, 399-416.

Woese, C. R. (1987). Bacterial evolution. Microbiol Rev 51, 221-271. 